\title{
Development and preliminary application of a method to assess river ecological status in the Hai River Basin, north China
}

\author{
Baoqing Shan ${ }^{1, *}$, Yuekui Ding ${ }^{1,2}$, Yu Zhao ${ }^{1,2}$ \\ 1. State Key Laboratory on Environmental Aquatic Chemistry, Research Center for Eco-Environmental Science, Chinese Academy of Science, \\ Beijing 100085, China \\ 2. University of Chinese Academy of Science, Beijing 100049, China
}

\section{A R T I C L E I N F O}

\section{Article history:}

Received 28 July 2015

Revised 9 October 2015

Accepted 10 October 2015

Available online 8 December 2015

Keywords:

Assessment

River ecological status

Hai River Basin

\begin{abstract}
A B S T R A C T
The river ecosystem in the Hai River Basin (HRB), an important economic region in China, is seriously degraded. With the aim of river restoration in the HRB, we developed a method to assess the river's ecological status and conducted a preliminary application of the method. The established method was a predictive model, which used macroinvertebrates as indicator organisms. The river's ecological status was determined by calculating the ratio of observed to expected values (O/E). The method included ecoregionalization according to natural factors, and the selection of reference sites based on combinations of habitat quality and macroinvertebrate community. Macroinvertebrate taxa included Insecta, Crustacea, Gastropoda, and Oligochaeta, with 39 families and 95 genera identified in the HRB. The HRB communities were dominated by pollution tolerant taxa, such as Lymnaeidae, Chironomus, Limnodrilus, Glyptotendipes, and Tubifex. The average ShannonWiener index was $1.40 \pm 0.5$, indicating a low biodiversity. In the river length of $3.31 \times 10^{4} \mathrm{~km}, 55 \%$ of the sites were designated poor, with a bad ecological status. Among nine secondary river systems, Luan and Zi-ya had the best and worst river conditions, respectively. Only 17 reference site groups were selected for river management in the 41 ecoregions examined. This study lays the foundation for river restoration and related research in the HRB, and we anticipate further developments of this novel method.

(C) 2015 The Research Center for Eco-Environmental Sciences, Chinese Academy of Sciences.
\end{abstract}

Published by Elsevier B.V.

\section{Introduction}

Early in 1972, the Clean Water Act advocated that the chemical, physical, and biological integrity of national aquatic ecosystems should be restored (Act, 1972). Gradually, people began to pay close attention to river health, and it became an important objective of river restoration and management schemes (Karr, 1999). In the early 1980s, the first biological method for assessment of stream ecological conditions was introduced by American ecologist Karr, known as the IBI (Index of Biological Integrity) (Karr, 1981). The IBI integrates multiparameters, including fish species, abundance, and reproduction, to indicate stream health condition. A multitude of assessment methods emerged following the IBI, such as RIVPACS (River Invertebrate Prediction and Classification System) in the UK (Wright, 1995), AUSRIVAS (Australian River

\footnotetext{
* Corresponding author.

E-mail address: bqshan@rcees.ac.cn (B. Shan).
} 
Assessment System) in Australia (Coysh et al., 2000), MEDPACS (The MEDiterranean Prediction And Classification System) for the Mediterranean (Poquet et al., 2009), EFI (European Fish Index) and AQEM (Development and Testing of an Integrated Assessment System for the Ecological Quality of Streams and Rivers throughout Europe using Benthic Macroinvertebrates) in the European Union (Breine et al., 2005; Hering et al., 2004). In addition, through continuous improvement, Chutter established SASS (South African Scoring System), a simple and rapid index method applied in South Africa (Dickens and Graham, 2002). All these methods use biological indicator (mainly fish and macroinvertebrate) to represent ecological status, and can be classified into multimetrics (e.g., IBI) and predictive models (e.g., RIVPACS, AUSRIVAS) (Boulton, 1999). Predictive models have been developed based on the correlations of physical, chemical and biological features with ecological status, with results represented by the ratio of observed $(O)$ to expected values $(E)$. Although this method has a complex modeling process, assessment results can be quickly obtained, indicating that it is highly applicable to river management.

The Hai River Basin (HRB), located in northern China, is one of the country's seven major river basins, with an area of $3.18 \times 10^{5} \mathrm{~km}^{2}$. The HRB is an important political, economic and cultural center in China, because it encompasses two developed cities, Beijing and Tianjin, which plays an important role in the development of the national economy. The river system, which provides food, water, industry, agriculture, amusement, shipping and commerce (Meng et al., 2009), supports the life and livelihood of the local populace. However, the increasing economic development has led to an increase in river pollution and ecological risks. In this area, the primary concerns are water depletion, structural imbalance and functional degradation of the river ecosystem (Yang et al., 2013). There is an urgent need for improvement in the Hai River system, which requires further knowledge of the river's ecological status.

To date, no studies have assessed the river status (or condition, health) of the whole HRB. Some theoretical studies of the region have reviewed river health, including the implications, technology and a case study of river health and its assessment (Tang et al., 2002; Dong, 2005a, 2005b; Ni and Liu, 2006). However, none of the existing assessment methods is universal, as they have been designed for specific regions with characterized river ecosystems. For instance, RIVPACS has a comprehensive geographical coverage of running-water sites throughout Great Britain, but has limited studies on small stream sites in Scotland (Cox et al., 1997). Further, the AUSRIVAS predictive system has been developed primarily for lotic environments. Future research and development of the AUSRIVAS system is aimed at widening its scope for use in estuarine and wetland environments (Ransom et al., 2005). The SASS is applicable to running rivers with various habitats, but not rivers with unitary habitats and still water habitats (Dickens and Graham, 2002). Thus, it is imperative to develop a suitable method for ecological assessments of the HRB, which has specific river ecosystem features.

As part of the government request for river restoration, it is essential to assess the ecological status of rivers. Supported by the 'National Water Pollution Control and Management
Technology Major Projects of China (2012ZX07203-006)', we aimed to develop a predictive model to assess the river ecological status of the HRB, which was applicable for the basin's river management. In addition, a preliminary application of the method was conducted based on detailed field surveys, to reveal the ecological condition of river ecosystems in the $\mathrm{HRB}$, and provide a theoretical basis for river recovery and management in the future.

\section{Study area}

The HRB, one of the largest basins in China, is located between $112^{\circ}-120^{\circ} \mathrm{E}$, and $35^{\circ}-43^{\circ} \mathrm{N}$. The HRB has an area of $3.18 \times 10^{5} \mathrm{~km}^{2}$, the boundaries of which are the Mongolian Plateau to the north, Yellow River to the south, Taihang Mountains to the west, and Bohai Bay to the east. The landforms in the HRB include mountain in the northwest, plains in the southeast, and a small area of plateau in the north. The basin is in the semi-arid temperate and half-moist monsoon climatic region, and the annual average temperature is between 0 and $14^{\circ} \mathrm{C}$. The annual average precipitation is $547 \mathrm{~mm}$, with $75 \%-85 \%$ occurring between June and August. There are nine secondary river systems in the HR: Luan, Bei-san, Yong-ding, Da-qing, Zi-ya, Hei-long-gang, Tu-hai-ma-jia, Zhang-wei, and Hai-gan (Fig. 1). The Luan river basin, located in the north of the $\mathrm{HRB}$, is $85 \%$ mountainous, with a small section of the Inner Mongolia Plateau and coastal plain. In the basin, most rivers have little human disturbance. The Bei-san river basin covers the Jingjinji Zone (Beijing-Tianjin-Hebei), China's important economic growth pole, and its rivers are seriously influenced by

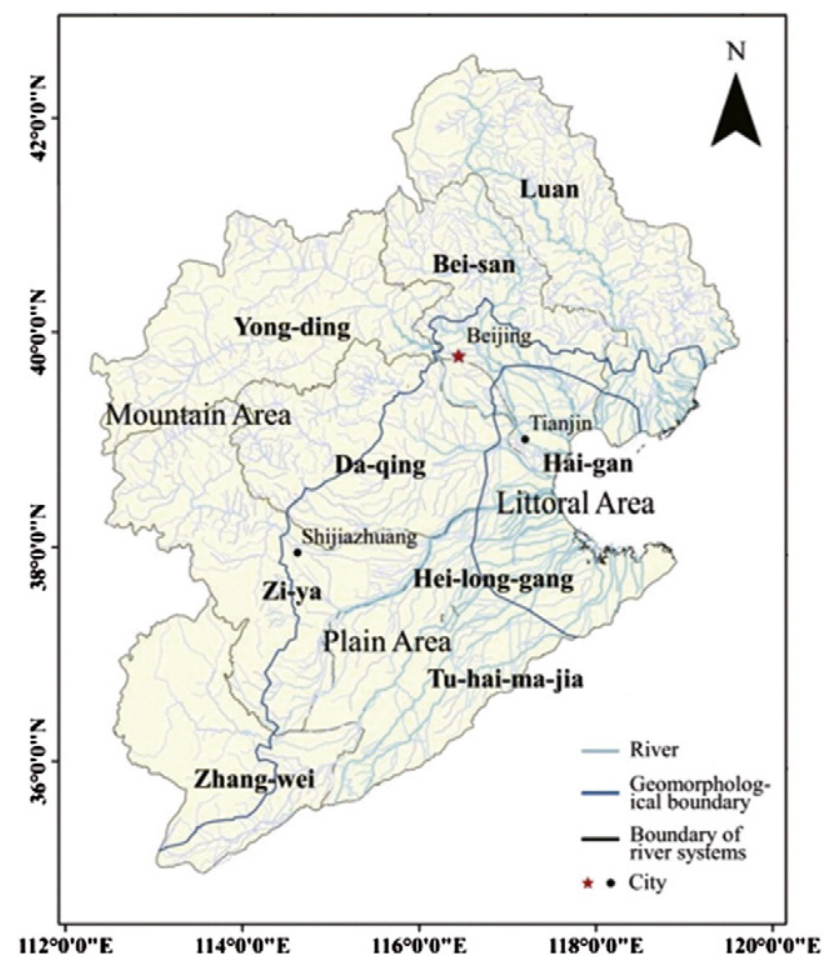

Fig. 1 - Hai River Basin and its river systems. 
human activities. The Da-qing river basin is in the middle of the $\mathrm{HRB}, 48 \%$ of which is mountainous, with relatively large areas of wetlands in the plain area, including the Baiyang Lake. The Yong-ding river basin is in the west of the HRB, next to the Da-qing river basin. Mountains cover $93 \%$ of the basin, with a small section in the Inner Mongolian Plateau. The basin to the south is the Zi-ya river basin, which is $64 \%$ mountainous. The plain area of this basin is one of the most polluted areas in the HRB, and there is often foul water in the river channel. The Hei-long-gang river basin is situated to the east of the $\mathrm{Zi}$-ya river basin; it has plain and littoral areas, with no mountains. The Hei-long-gang river system is composed of artificial excavation and reconstructed river channels, and is seriously affected by human activity. Analogously, the Tu-hai-ma-jia river basin also covers plain and littoral area, and has a simple river system. The Zhang-wei river basin is in the southwest corner of the HRB, has $63 \%$ mountain area, and mining in some regions is an important factor affecting river ecological conditions. The Hai-gan river basin is adjacent to the Bohai Gulf, and has a small area and a simple river system.

The HRB has been put under great pressure from human activities. With a high population density, the HRB has experienced rapid urbanization, which directly affected water quality (Wang et al., 2014). Specifically, the rate of urbanization has increased from 18\% in 1978 to 46\% in 2009 (Jia et al., 2012; Li, 2013). Artificial land use spread widely and has caused great stress to the river ecosystems, especially in the plain areas where land use was dominated by farmland (83\%), as well as swamps, inland waters, salt pans, construction land, and urban land. Vast farming land occupied the riparian area, impeding the communication between aquatic and terrestrial organisms and reducing the river's function as flood storage. Furthermore, the discharge of pollutants has dramatically increased over time. The HRB has become one of the most polluted basins in China, and water shortages and water pollution are major problems facing rivers in the HRB, especially in the plain area (Liu et al., 2010; Yang et al., 2013). In addition, human activities (cultivation, irrigation, deforestation, water conservancy projects) have changed the hydrological cycle and space-time distribution (Wang et al., 2013). Water pollution, habitat degradation, and ecological deterioration caused by intensive human disturbance are prominent problems affecting river systems in the HRB.

\section{Development of the method}

We established a method to assess the ecological status of HRB's river ecosystems, as shown in Fig. 2. This method was not a complicated mathematical formula, but a rigorous pattern. The major index sets included river habitat attributes and macroinvertebrate communities. The key issue to be addressed was establishing the reference condition. In the method, reference sites were selected that had suffered minimal human disturbance, based on field surveys and assessment of river habitat and macroinvertebrate community. In each ecoregion, these reference sites were integrated into reference groups, and consecutive reference sites were combined to form reference conditions, which could be river segments or small catchments. Reference groups produced expected values (E) of macroinvertebrates, and observed sites generated observed values $(\mathrm{O})$. The ecological status of the river ecosystem (ESR) was represented by the ratio of the observed value to the expected value (O/E).

\subsection{Biological indicator-macroinvertebrates}

Macroinvertebrates were selected as bio-indicators for assessment of river ecological status in the HRB, specifically using

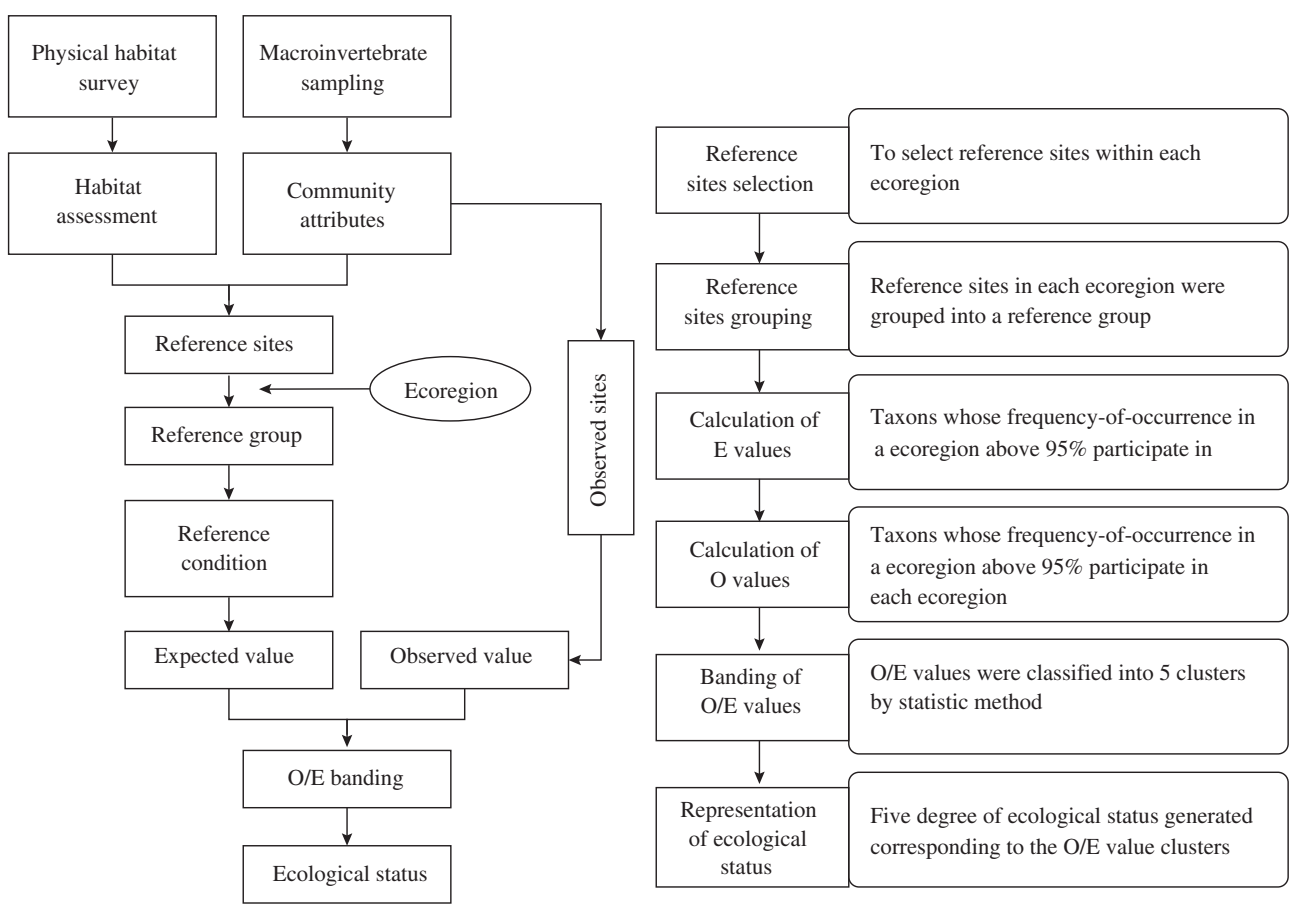

Fig. 2 - Frame (left) and running process (right) of the method. 
genera. Biological indicators used to indicate the condition of aquatic ecosystems included macroscopic plants, fish, benthic invertebrates, phytoplankton and phytobenthos, with macroscopic plants and benthic invertebrates as the most widely applied indicators (Birk et al., 2012). As biological indicators, macroinvertebrates have many advantages. (a) They have relatively long life cycles, which is convenient for analyzing temporal changes caused by perturbations (Lenat et al., 1980). (b) They are ubiquitous (Lenat et al., 1980). (c) They have primarily sedentary behavior, and thus reflect external disturbances (Slack et al., 1973; Hellawell, 1986). In addition, macroinvertebrates are easy to sample and identify, have a wide range of forms and habits, and thus their communities are, on the whole, sensitive indicators (Elliott et al., 1980). In the HRB, water shortage, water pollution and human disturbance have proved to be the main problems affecting river ecosystem. As fish and aquatic plants are rarely found in partial black water rivers, they are not appropriate for ecological assessment. Macroinvertebrates were suitable as an indicator for the HRB, which has heavy polluted and degraded river ecosystems.

\subsection{Freshwater ecoregionalization}

Ecoregionalization is an important foundation for assessing ecological status of river ecosystems in the HRB, because different ecoregions with homogenous natural features act as the foundation of comparing ecological conditions between different sites. The HRB has a large area and differential natural characteristics, which determine the heterogeneity of features of river ecosystems. On a large scale, the characteristics of river ecosystems are controlled by natural factors including climate, geology, landform and soil. The interactions of these factors produce independent zones with specific attributes of river ecosystems. In addition, river channels in each secondary basin form independent river networks (The Hai River Basin, 1997). Hence, the indicators selected for the HRB zonation included climate, geology, landform, soil and secondary basin.

Ecoregionalization was conducted by stepped zoning, according to each boundary. First, we determined the boundaries of selected indicators in the HRB. Climate zoning was conducted using the boundary of the climate district of China. The monograph of "The HRB" provided the boundaries of climate, geology, landform and soil (The Editorial Board of Hai River, 1997). Second, zones were ordered according to the boundaries of the indicators. Then the boundaries of the zones produced based on each of the factors were overlaid to produce ecoregions. The HRB was partitioned into 41 ecoregions, which were then coded corresponding to their different indicator combinations. The coding order of the indicators was climate, geology, landform, soil, and river system. Each indicator had a code representing its class. For instance, the ecoregion with code "11111" means "Semi-arid-Consolidated rock outcroppingMountain-Chestnut soil-Luan ecoregion" (Fig. 3; Table 1).

\subsection{Reference condition}

Establishing the reference sites is important for conducting river restoration projects and evaluating restoration success (Brewer and Menzel, 2009). Reference condition refers to a

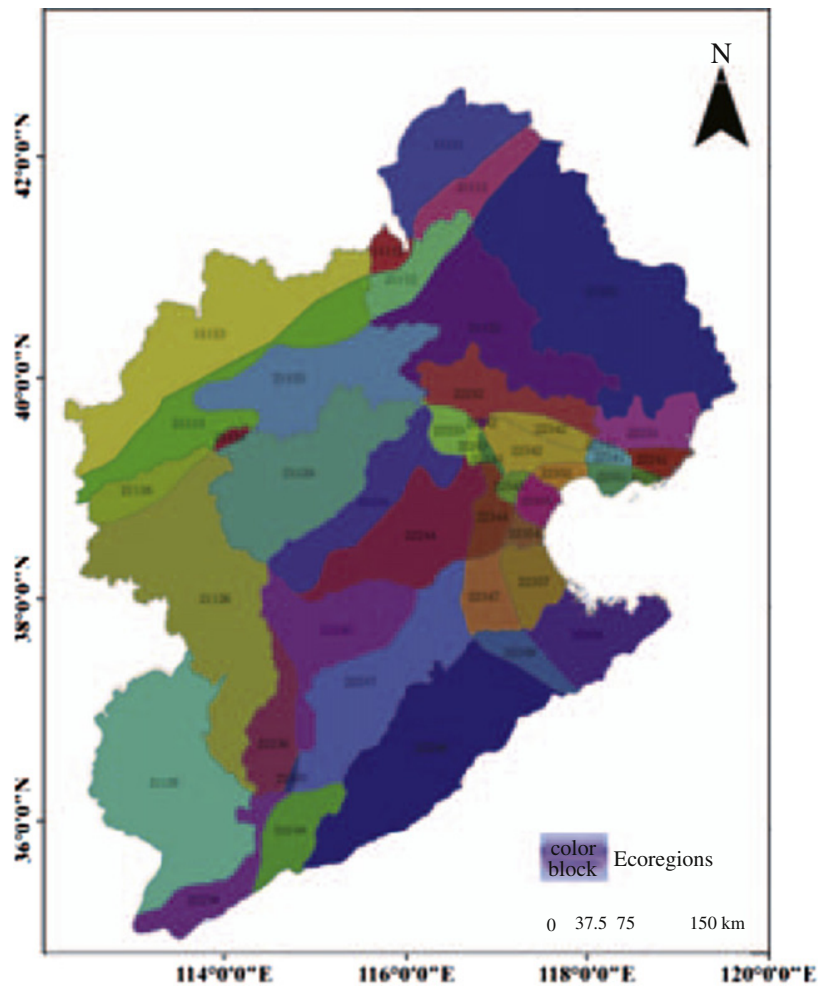

Fig. 3 - Ecoregions with codes in the Hai River Basin.

reach with favorable ecological status, which acts as a baseline for the evaluation of different ecological levels. There are several interpretations of reference condition, including minimally disturbed condition, historical condition,

Table 1 - Codes of ecoregions in the Hai River Basin.

\begin{tabular}{|c|c|c|c|}
\hline Indicator & Category & Code & Position \\
\hline \multirow[t]{2}{*}{ Climate } & Semi-arid region & 1 & Northwest \\
\hline & Semi-humid region & 2 & Southeast \\
\hline \multirow[t]{2}{*}{ Geology } & $\begin{array}{l}\text { Consolidated rock } \\
\text { outcropping region }\end{array}$ & 1 & Northwest \\
\hline & $\begin{array}{l}\text { Loose material } \\
\text { accumulation region }\end{array}$ & 2 & Southeast \\
\hline \multirow[t]{3}{*}{ Landform } & Mountain area & 1 & Northwest \\
\hline & Plain area & 2 & Central \\
\hline & Littoral area & 3 & Southeast \\
\hline \multirow[t]{5}{*}{ Soil } & Chestnut soil area & 1 & Northwest \\
\hline & Cinnamon soil area & 2 & Northwest-central \\
\hline & Loessial soil area & 3 & Central \\
\hline & Moisture soil area & 4 & Southeast-central \\
\hline & Solonchak area & 5 & Southwest \\
\hline \multirow{9}{*}{$\begin{array}{l}\text { River } \\
\text { system }\end{array}$} & Luan & 1 & Northeast \\
\hline & Bei-san & 2 & Northeast-central \\
\hline & Yong-ding & 3 & Northwest \\
\hline & Da-qing & 4 & Central \\
\hline & Hai-gan & 5 & East \\
\hline & Zi-ya & 6 & Southwest-central \\
\hline & Hei-long-gang & 7 & Southeast-central \\
\hline & Tu-hai-ma-jia & 8 & Southeast \\
\hline & Zhang-wei & 9 & Southwest \\
\hline
\end{tabular}


least disturbed condition, and best attainable condition (Stoddard et al., 2006). The least disturbed condition was chosen as the reference condition in the HRB, because disturbances exist throughout the HRB, no natural rivers could be found, and there is a lack of historical data.

On the basis of freshwater ecoregionalization, river habitat quality and benthic community were combined to select the reference sites. Reference condition, which may apply to a river segment or small catchment, was obtained by a combination of continuous reference sites. The process of selecting reference conditions is shown in Fig. 4. First, the river habitat quality should be assessed based on field surveys of river channel attributes, bank vegetation, and adjacent land use. Applying the principle of Riparian, Channel, and Environmental's scoring system (Robert and Petersen, 1992), nine index sets were surveyed and scored based on the specificities of the river environment in the HRB. The basis for assessing habitat quality included: habitat diversity and naturalness, continuity of bank vegetation, and cleanliness and stability of channel (Table 2). A five-point scale was applied and the equation used to calculate the site score was:

$\mathrm{Q}=\left(\sum_{i=1}^{n} \mathrm{Si}\right) /(5 \times n)$

where, $Q$ was total score, $S_{i}$ represented the score of the ith index set, and $n$ was the number of index set (9) (Table 2). Banding of $Q$ value, which ranged $0-1$, produced five degrees ("excellent", "good", "moderate", "poor", "bad") of habitat quality. Sites with "excellent" and "good" habitat levels were selected, as were identified as suffering minimal human disturbance. More details on the evaluation of river habitat quality can be provided to readers if necessary.

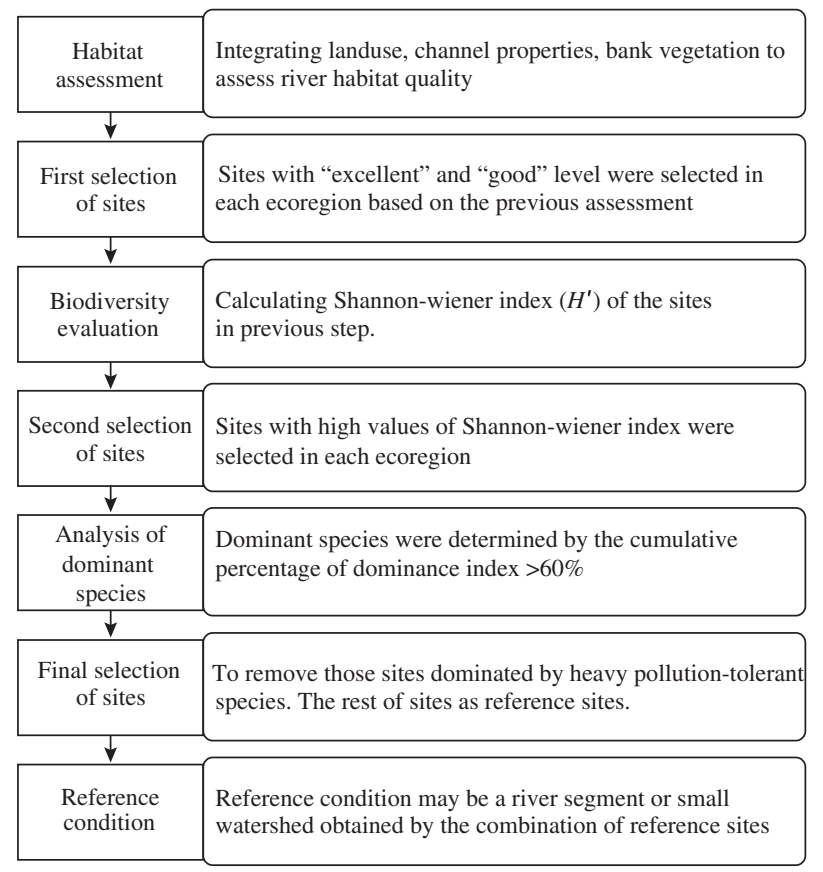

Fig. 4-Method for determining reference conditions in the Hai River Basin.

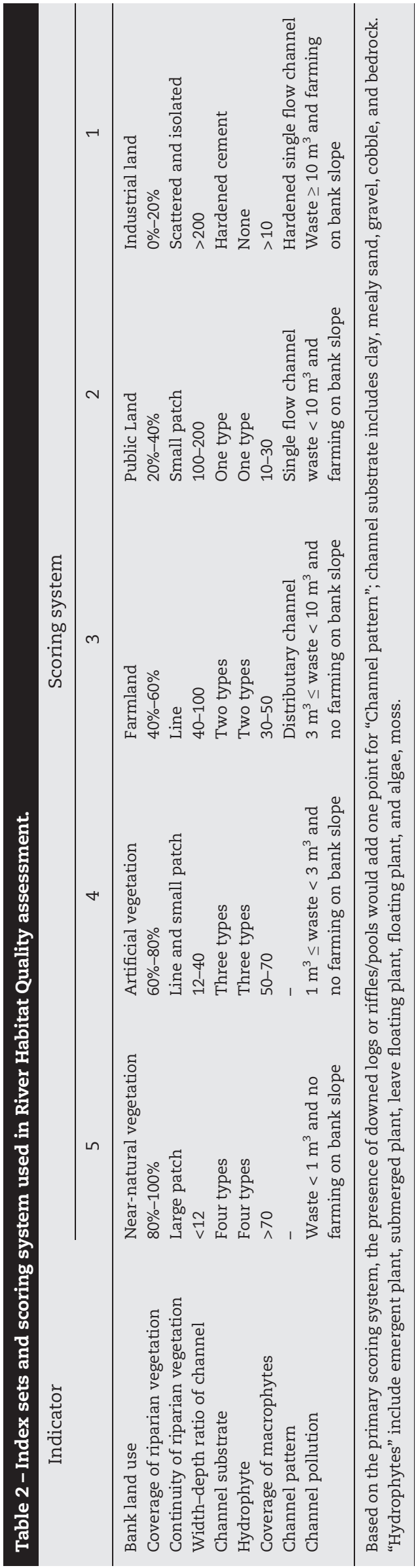


Second, the Shannon-Wiener index was used to analyze the macroinvertebrate biodiversity at the sites selected. The index is the most widely used index characterizing species richness and abundance simultaneously. Index values were classified into five clusters (potentially corresponding to the five habitat quality degrees) by K-means cluster, then the sites selected in the upper two clusters, which was based on the understanding that a favorable ecological status should support high biodiversity. Third, the dominant species of the sites selected were analyzed, determined by the cumulative percentage of dominance index $>60 \%$. The sites dominated by heavy pollution-tolerant species were removed, based on the understanding that good ecological status should not support a community dominated by those species. The rest of the sites were confirmed as reference sites. The process of reference site selection was conducted in each established ecoregion. If possible, consecutive reference sites were combined to form reference conditions, which could be a segment or small catchment.

\subsection{Representation of ecological status}

The ratio of observed to expected values (O/E) was calculated to characterize the river ecological status in each ecoregion. Different value ranges of $\mathrm{O} / \mathrm{E}$, corresponding to ecological status level, were obtained by the value banding using the $\mathrm{K}$-means cluster. Five degrees of ecological status were designed, including "excellent", "good", "moderate", "poor", and "bad". Expected values (E) were calculated as:

$E=\sum_{i, j=1}^{n} P_{i} G_{j}$

where, $P_{i}$ was the probability of ith taxon belonging to the reference group, $G_{j}$ was the probability of the $j$ th site belonging to the reference group, and $n$ was the total number of macroinvertebrate taxa. As the sites within one ecoregion were identified as having a naturally homogenous environment, the $P_{i}$ value was 1 . The formula for calculating observed values was:

$O=\sum_{i=1}^{N} \sum_{j=1}^{M} \frac{n_{i j}}{N}$

where, $N$ and $M$ were the total number of sample and taxa respectively, and $n_{i j}$ was the number of sample which contained $j$ th taxon. The taxa with a frequency of occurrence below $5 \%$ were excluded.

\section{Application of the method in the HRB}

\subsection{Sampling sites}

In the HRB, 410 sampling sites were selected (Fig. 5). Within each ecoregion, sampling sites were selected based on the following principles. (1) Sampling sites covered the 2nd- to 5th-order rivers. (2) Our sites were in accordance with and included present monitoring sites set up by hydrology departments, so as to carry out long-term monitoring. (3) Considering the areas of the river systems and complexity of the river network, river systems with the larger areas had more sampling sites,

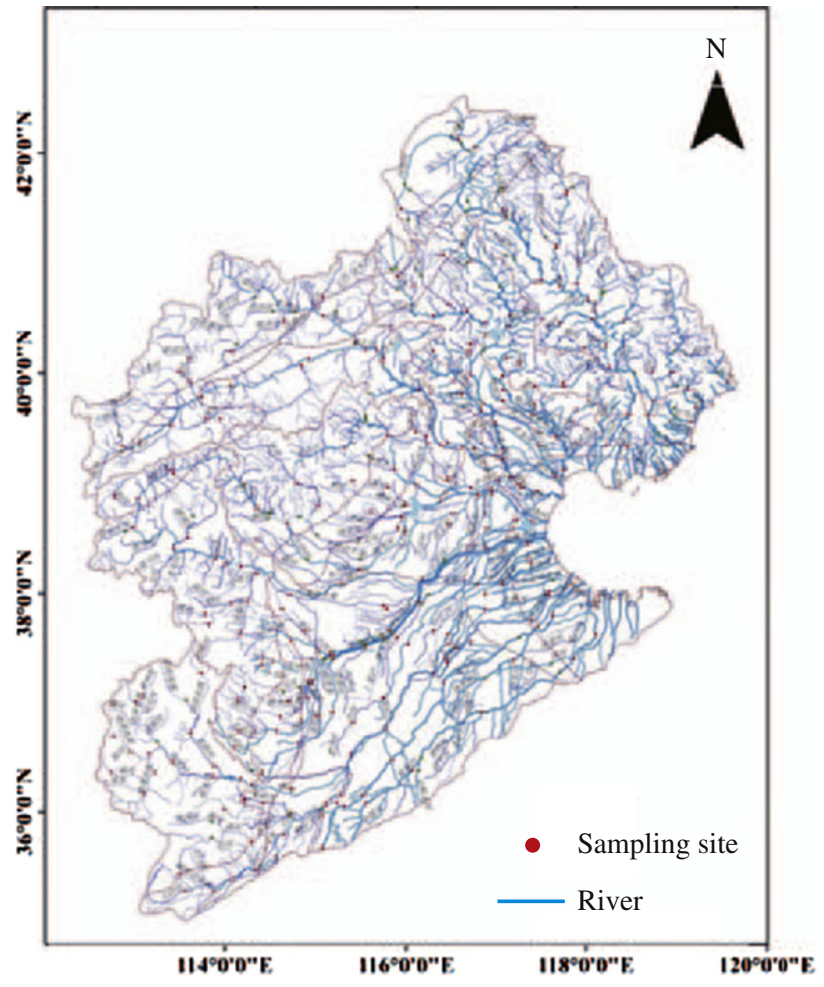

Fig. 5 - Sampling sites in the Hai River Basin.

and fewer sites were selected in river systems with small areas and simple river networks. (4) Sampling sites were selected both on major and branch channels to study the differences and relationships between them. (5) Sites were selected upstream and downstream of sewage outlets. (6) Comparatively fewer sites were selected for those reaches with uniform characteristics.

\subsection{Field survey and sample treatment}

To apply the assessment method, it was necessary to conduct an investigation of macroinvertebrate communities and river habitats in the whole basin. We took 3 months (from May to August in 2013) to complete the field survey. Macroinvertebrates sampling procedures were conducted in various habitats (run, riffle, pool, backwater, drop water). Benthic sampling was a combination of quantitative and qualitative sampling. Qualitative samples were taken using a standard D-net with $0.5 \mathrm{~mm}$ mesh. A surber with an area of $0.3 \mathrm{~m} \times 0.3 \mathrm{~m}$ was used for quantitative sampling. Large rocks, woody debris, and leaves were scrubbed to dislodge organisms clinging to these substrates. Samples were preserved with $10 \%$ formalin in the field, and then transformed to $75 \%$ ethanol in the laboratory. Organisms were sorted with forceps on white China plates. Taxa were identified to genus level, which was cost-effective and sufficient to detect differences for a rapid assessment of water quality or a demonstration of biotic relationships on a broader scale (Schmidt-Kloiber and Nijboer, 2004).

A comprehensive field survey method was applied to investigate physical river habitat. The indicators investigated 
included basic information on sampling sites (e.g., longitude and latitude, altitude, administrative district, date and time, weather) channel characteristics, channel pollution, bank vegetation, and adjacent land use. Indicators on the field survey sheet were integrated into nine indicator combinations, which covered four survey aspects (channel feature, bank vegetation, adjacent land use and pollution condition) and were then scored according to the degree of human stress. Total score of a site represented river habitat quality, which could be "excellent", "good", "moderate", "poor", and "bad". River habitat quality was assessed at 410 sampling sites distributed evenly in 41 ecoregions in the HRB.

\subsection{Macroinvertebrate community and river habitat quality}

Table 3 shows the profile of macroinvertebrate assemblages in the HRB. The groups of macroinvertebrate investigated in the HRB included Insecta, Crustacea, Gastropoda, and Oligochaeta. There were 39 families and 95 genera in the $\mathrm{HRB}$, which had differing distributions in each secondary river system. Bei-san had the most families (37), followed by Da-qing with 35 families. River systems with low family abundance were Hei-long-gang (only 20), Zhang-wei (21), and Tu-hai-ma-jia (22). Genera had a similar distribution to families, and the Luan river system had the most genera. Yong-ding, with 32 families, only had 35 genera, indicating a low biodiversity. Secondary river systems, with different levels of economic development, had different river conditions affected by human activities, and the macroinvertebrate abundance differed greatly. Although the HRB covers 41 freshwater ecoregions, there were several common families, including Odonata, Ephemeridae, Hirudinidae, Diptera, Coleoptera, Viviparidae, and Lymnaeidae. However, variability appeared simultaneously, mainly in the relative proportion of these groups and genera differences in secondary river systems. The value, range and average Shannon-Wiener index was $0.22-2.73$ and $1.40 \pm 0.55$, respectively. The Zi-ya and Yong-ding river systems had the lowest biodiversity, with averages of $1.20 \pm 0.50$ and $1.21 \pm 0.54$ (Table 3). Generally, there was a low biodiversity of macroinvertebrates in the HRB.

The assessment results showed that the river habitats of the HRB are seriously degraded (Table 4). The "moderate" level of river habitat quality had the highest proportion at 34.56\%, with "poor" and "bad" of $26.72 \%$, and $15.69 \%$, respectively; while the proportions of "excellent" and "good" were $5.64 \%$ and $17.4 \%$,

Table 4 - Proportion of sampling sites with different river habitat qualities in river systems.

\begin{tabular}{lrrrrr} 
River system & Excellent & Good & Moderate & Poor & Bad \\
\hline Luan & $21.43 \%$ & $30.36 \%$ & $28.57 \%$ & $17.86 \%$ & $1.79 \%$ \\
Zi-ya & $2.79 \%$ & $6.51 \%$ & $37.21 \%$ & $28.37 \%$ & $25.12 \%$ \\
Tu-hai-ma-jia & $0.00 \%$ & $23.81 \%$ & $23.81 \%$ & $38.10 \%$ & $14.29 \%$ \\
Da-qing & $0.00 \%$ & $16.22 \%$ & $29.73 \%$ & $21.62 \%$ & $32.43 \%$ \\
Bei-san & $2.13 \%$ & $10.64 \%$ & $34.04 \%$ & $38.30 \%$ & $13.83 \%$ \\
Yong-ding & $9.38 \%$ & $18.75 \%$ & $28.13 \%$ & $28.13 \%$ & $15.63 \%$ \\
Zhangwei & $8.11 \%$ & $16.22 \%$ & $43.24 \%$ & $24.32 \%$ & $9.11 \%$ \\
Hei-long-gang & $0.00 \%$ & $12.90 \%$ & $25.81 \%$ & $45.16 \%$ & $16.13 \%$ \\
Total basin & $5.64 \%$ & $17.40 \%$ & $34.56 \%$ & $26.72 \%$ & $15.69 \%$ \\
\hline
\end{tabular}


Table 5 - Distribution of ESR in each secondary river system of Hai River Basin.

\begin{tabular}{|c|c|c|c|c|c|c|c|c|c|c|}
\hline \multirow{2}{*}{$\begin{array}{c}\text { River } \\
\text { system }\end{array}$} & \multicolumn{2}{|c|}{ Excellent } & \multicolumn{2}{|c|}{ Good } & \multicolumn{2}{|c|}{ Moderate } & \multicolumn{2}{|c|}{ Poor } & \multicolumn{2}{|r|}{ Bad } \\
\hline & $\begin{array}{c}\mathrm{O} / \mathrm{E} \\
\text { value }\end{array}$ & Percentage & $\begin{array}{c}\mathrm{O} / \mathrm{E} \\
\text { value }\end{array}$ & Percentage & $\begin{array}{c}\text { O/E } \\
\text { value }\end{array}$ & Percentage & $\begin{array}{c}\text { O/E } \\
\text { value }\end{array}$ & Percentage & $\begin{array}{c}\text { O/E } \\
\text { value }\end{array}$ & Percentage \\
\hline Luan & $0.54-0.85$ & $46.67 \%$ & $0.46-0.49$ & $6.67 \%$ & $0.37-0.43$ & $13.33 \%$ & $0.18-0.26$ & $23.33 \%$ & $0.09-0.12$ & $10.00 \%$ \\
\hline Bei-san & $0.69-0.82$ & $24.53 \%$ & 0/59-0.66 & $11.32 \%$ & $0.42-0.56$ & $22.64 \%$ & $0.22-0.38$ & $18.87 \%$ & $0.07-0.18$ & $24.53 \%$ \\
\hline Yong-ding & $0.53-0.70$ & $17.39 \%$ & $0.46-0.50$ & $8.69 \%$ & $0.33-0.40$ & $13.04 \%$ & $0.20-0.27$ & $26.08 \%$ & $0.05-0.17$ & $30.43 \%$ \\
\hline Da-qing & $0.75-0.79$ & $28.21 \%$ & $0.48-0.62$ & $5.13 \%$ & $0.41-0.43$ & $12.82 \%$ & $0.20-0.36$ & $28.21 \%$ & $0.10-0.17$ & $25.64 \%$ \\
\hline Zi-ya & $0.58-0.67$ & $9.30 \%$ & $0.42-0.50$ & $5.81 \%$ & $0.29-0.37$ & $16.09 \%$ & $0.11-0.20$ & $16.09 \%$ & $0.01-0.06$ & $52.33 \%$ \\
\hline Tu-hai-ma-jia & $0.67-0.83$ & $18.52 \%$ & $0.56-0.64$ & $3.70 \%$ & $0.43-0.48$ & $22.22 \%$ & $0.24-0.37$ & $14.81 \%$ & $0.08-0.13$ & $40.74 \%$ \\
\hline Hei-long-gang & $0.58-0.89$ & $19.35 \%$ & $0.42-0.55$ & $3.23 \%$ & $0.34-0.37$ & $3.23 \%$ & $0.21-0.28$ & $29.03 \%$ & $0.07-0.14$ & $45.16 \%$ \\
\hline Zhang-wei & $0.58-0.66$ & $36.84 \%$ & $0.40-0.53$ & $5.26 \%$ & $0.22-0.27$ & $15.79 \%$ & $0.16-0.18$ & $21.05 \%$ & $0.09-0.13$ & $21.05 \%$ \\
\hline Total basin & $0.53-0.89$ & $24.64 \%$ & $0.40-0.64$ & $6.79 \%$ & $0.22-0.48$ & $14.29 \%$ & $0.11-0.38$ & $22.50 \%$ & $0.01-0.17$ & $30.71 \%$ \\
\hline
\end{tabular}

respectively, indicating favorable habitat conditions. In addition, the "moderate" level represented a vulnerable habitat condition, and showed that over $30 \%$ of the river habitat will probably degrade further under human disturbance. It was the Luan river system that had the best river habitat, and the proportion of the sites with "excellent" and "good" habitat was $51 \%$. The river habitat of the Bei-san river system had a "polarized character", with the sites around Beijing city in a good condition with 52\% "excellent" and "good" habitat, while the sites around Tianjin city had poor river habitat, and the proportion of "good" river habitat was $14.55 \%$. Habitat degradation in the Zi-ya river system was the most seriously degraded, with "excellent" and "good" habitat as low as 9.30\%.

\subsection{River ecological status}

The ESR in the HRB was determined by applying the established method. There were 363 sites assessed for ecological state (excluding those site with dry channels), accounting for a river length of $3.31 \times 10^{4} \mathrm{~km}$. The $\mathrm{O} / \mathrm{E}$ values ranged from 0.01 to 0.89 (Table 5), and were distributed abnormally. There was a large proportion (88\%) of sites with O/E value below $0.50,36 \%$ of which has $\mathrm{O} / \mathrm{E}$ between 0 and 1, denoting poor ecological conditions in the river systems. Banding of O/E values was performed within each ecoregion to represent different ecological conditions. The results showed a poor ESR in the HRB (Table 5 and Fig. 6). Over half of the sites had "poor" and "bad" ESR, and the proportion of "excellent" and "good" was less than $30 \%$. There were differences among secondary river system's ESR. The Luan river system had a high level of ESR, and the percentage of "excellent" and "good" ESR was 53\%. The "second-best" river system was Zhang-wei, which had a large proportion (nearly $42 \%$ ) of sites with "excellent" and "good" ESR. For the river systems of Bei-san, Yong-ding, and Da-qing, the proportion of sites with "excellent" and "good" ESR exceeded 30\%, which indicated a relatively good ESR. The Zi-ya river system had serious degradation of the river ecosystem, and the proportion of the sites with "poor" and "bad" was up to $68 \%$, while only $15 \%$ of the
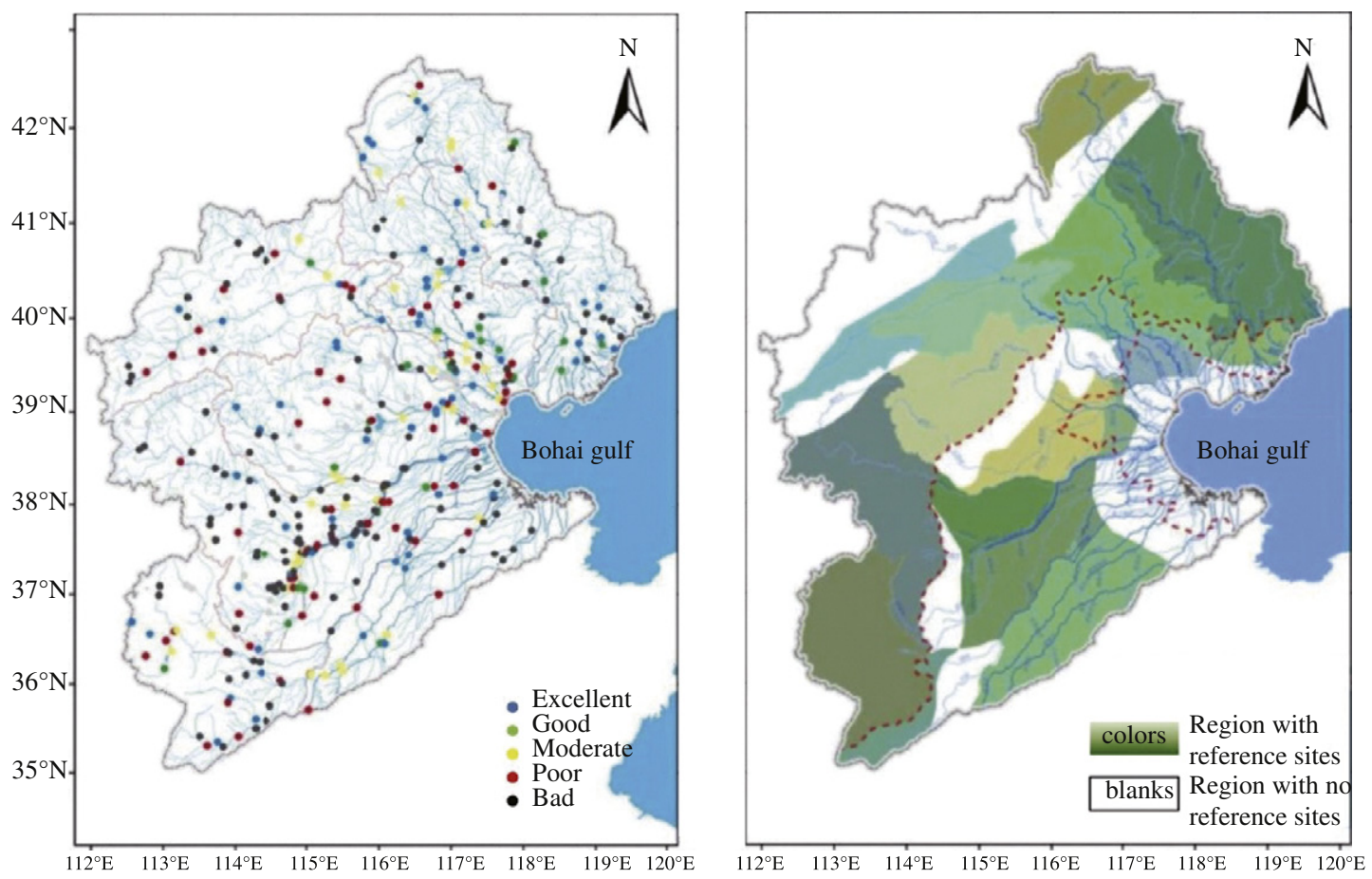

Fig. 6 - River ecological status and ecoregions with reference group in the Hai River Basin. 


\begin{tabular}{|c|c|c|c|}
\hline $\begin{array}{c}\text { River } \\
\text { system }\end{array}$ & $\begin{array}{l}\text { Ecoregion } \\
\text { code }\end{array}$ & $\begin{array}{l}\text { Number of } \\
\text { reference site }\end{array}$ & $\begin{array}{c}\text { River } \\
\text { ecological } \\
\text { status }\end{array}$ \\
\hline \multirow[t]{3}{*}{ Luan } & 11111 & 5 & Excellent/good \\
\hline & 21121 & 6 & Excellent/good \\
\hline & 22231 & 4 & Excellent/good \\
\hline \multirow{3}{*}{ Bei-san } & 21122 & 4 & Excellent/good \\
\hline & 22232 & 4 & Excellent/good \\
\hline & 22342 & 5 & Excellent/good \\
\hline \multirow[t]{2}{*}{ Yong-ding } & 21113 & 5 & Excellent/good \\
\hline & 21123 & 5 & Excellent/good \\
\hline \multirow[t]{3}{*}{ Da-qing } & 21124 & 5 & Excellent/good \\
\hline & 22244 & 4 & Excellent/good \\
\hline & 22344 & 4 & Excellent/good \\
\hline \multirow[t]{2}{*}{ Zi-ya } & 21126 & 5 & Excellent/good \\
\hline & 22246 & 5 & Excellent/good \\
\hline Hei-long-gang & 22247 & 5 & Excellent/good \\
\hline Tu-hai-ma-jia & 22248 & 6 & Excellent/good \\
\hline \multirow[t]{2}{*}{ Zhang-wei } & 21129 & 6 & Excellent/good \\
\hline & 22239 & 4 & Excellent/good \\
\hline
\end{tabular}

sites had "excellent" and "good" ESR. River ecosystems were also seriously degraded in the Hei-long-gang and Tu-hai-ma-jia river systems, which had nearly 20\% "excellent" and "good" ESR.

Following the procedure of reference site selection, we achieved the reference sites in the HRB. Reference sites in the same ecoregion were placed into common groups. There were 17 reference site groups selected in 41 ecoregions in the HRB (Fig. 6, Table 6), indicating the universally poor ESR. Hai-gan, an extremely simple river system with a small area and few sample sites, had no reference sites. According to the river ecological condition within each ecoregion, each group had at least four reference sites, lower than the original concept of 5 (Table 6). Reference site groups were also scarce in some other secondary river systems. There were 24 ecoregions with no reference sites. The Zi-ya, Tu-hai-ma-jia, and Hei-long-gang river systems had only one or two reference site groups (Fig. 6). Because of the poor river conditions in the HRB, it was difficult to select more reference sites within several ecoregions owing to serious degradation. Discontinuity of reference sites unfortunately made a fantasy of reference condition.

\section{Discussion}

\subsection{Highlights of the method}

The method, developed for the assessment of river ecological status in the HRB, has a series of procedures, including assessment steps and field survey. Two highlights of the method are the ecoregionalization and selection of reference site, which guarantee rationalities of the process and results of ecological assessment. A preliminary application revealed the river ecological status in the whole basin and each secondary river system, laying a critical foundation for river restoration and management in the HRB. This method can extend in the future with further improvements, depending on features of other regions.
There was a unique feature during the selection of reference site in the HRB, with reference sites selected based on the evaluation of habitat quality and biodiversity. In contrast, in the AUSRIVAS model, a classic predictive model, reference sites were selected based on environment condition, considering the different effects of large scale (land use, hydrological regime, current and historical mining activity) and local scale impacts (piparian zone characteristics, channel modification, de-snagging and instream vegetation removal, floodplain condition, human access, stock access, bank condition, point source impacts) (Coysh et al., 2000). Considering the specificities of river habitat and human disturbance, targeted habitat indicators were developed in our method, which encompassed channel characteristics, bank vegetation, and adjacent land use. These indicators represented not only common river habitat and the surrounding environment, but also the peculiarity in the HRB. For instance, cropping on the bank slope and solid waste on the bank were all distinctive features of the HRB. In addition, biodiversity evaluation was a necessary step to select reference sites, indicating reliability in the HRB suffered from a high level of human disturbance.

Ecoregionalization provides guarantees for scientific assessment of river ecological status. The selected factors, including climate, geology, landform, and soil, were all controllable characteristics of river ecosystems on a region scale. Sites within one ecoregion were identified as a common group, based on the principle that each ecoregion constrained a distinctive river type. Climatic regions can determine and alter a river's hydrologic regime (Davis et al., 2013), the process of sedimentation (Andrews and Antweiler, 2012), and ecosystem metabolism (Marcarelli et al., 2010; Shen and Sun, 2012). The geological environment determines the basic geochemical composition of substrate, and erosion and sedimentation processes in rivers (Andrews and Antweiler, 2012; Dudgeon, 2012). Potentially, geology influences the magnitude that land use impacts on invertebrate communities (Shearer and Young, 2011). Geomorphology has a profound impact on physical variables of channel and flow type (Wei and Sun, 2009). Soil types influence the spatial distribution and evolution process of land use (Marsh, 1997; Filser, et al., 2002; Huang, et al., 2010), which indirectly affect habitat, material input and output of river ecosystem. Furthermore, surface soil type is crucially important for river sediments (Sajedi et al., 1997). Taking into account all the aforementioned variables, reasonable ecoregionalization was performed in the HRB.

However, there appears to be some deficiencies of this method. Just as the AUSRIVAS model, there must be a bias to use macroinvertebrate indicating comprehensive ecological status, considering that living space of macroinvertebrate is limited in sediment. In our method, assessment of habitat quality embraces indicators referring to every aspects of physical environment, including channel, bank, and adjacent land use, which synthetically display habitat condition and reduce the bias. This method is also expected to apply in other regions or other aquatic ecosystems. Core modules are "ecoregionalization" and "selection of reference site". If a study area is sufficiently large and has obvious climatic and geographic differentiation, ecoregionalization has a scientific significance. The selection of reference site is based on 
current status of rivers and other ecosystems, which raise the convenience of application. Thus, adding a strict process of selection of reference site, this assessing method can be successfully applied.

\subsection{Notes on the application of the method}

This method is based on the presence/absence of macroinvertebrate taxa, and therefore, it is crucial to find as many animals as possible. Macroinvertebrates should be quantitatively sampled in each mesohabitat: a combination of water depth, velocity, aquatic plant, and substratum. During qualitative sampling, several surveyors should be sent to look for animals everywhere, such as under stones, plant debris, and even solid waste in the channel. Sampling after immediate rain should be avoided in the future, and more time should be allowed for re-colonization of animals after spates. After live picking during the field survey, animals should be carefully placed in polythene bottles during the evening, at least $30 \mathrm{~min}$ for each sample. At least two teams are needed for the identification of animals. After meticulous identification, a randomly selected $5 \%$ of invertebrate samples from one teams' production should be re-identified by another team to ensure accuracy of the understanding of animals.

\section{Conclusions}

Based on the deterioration of river ecosystems and the need for river restoration in the HRB, we developed a method for river status assessment and performed a preliminary application. Several conclusions were drawn as follows. 1) The method was a predictive model, using the presence/absence data of macroinvertebrate to assess ecological status. Highlights of the method include ecoregionalization according to natural factors, and selection of reference sites based on a combination of habitat quality and macroinvertebrate community. Furthermore, the method calculates the O/E value and uses a banding scheme to represent the river ecological condition. 2) Macroinvertebrate taxa included Insecta, Crustacea, Gastropoda, and Oligochaeta, with 39 families and 95 genera identified in the HRB, which was dominated by pollution tolerant taxa (i.e. Lymnaeidae, Chironomus, Limnodrilus, Glyptotendipes, Tubifex). Assessment of river ecological status indicated that $55 \%$ of the sites, accounting for a river length of $3.31 \times 10^{4} \mathrm{~km}$, were designated poor and bad river ecological status. Secondary river systems with the best and the worst river condition were Luan and Zi-ya, respectively. There was low biodiversity, with an average Shannon-Wiener index of $1.40 \pm 0.55$. Overall, the river habitat was seriously degraded, specifically, $42.41 \%$ of the sites were designated poor and bad. Only 17 reference site groups were selected for future river management.

\section{Acknowledgments}

Financial support was provided by the 'National Water Pollution Control and Management Technology Major Projects of China (2012ZX07203-006)'. Many people from several institutes participated in the field work, and we especially thank Dr. Xiaoguang You and Dr. Tao Yang from Beijing Normal University, Dr. Weijie Huo from the China Institute of Water Resources and Hydropower Reserch, Dr. Qingnan Li from the Chinese Academy of Environmental Sciences, and Dr. Jiating Zhao from Institute of High Energy Physics Chinese Academy of Sciences. Thanks are also due to Dr. Juguang Wang and his assistants from the College Of Fisheries at Huazhong Agricultural University, for the identification of macroinvertebrate species.

\section{R E F E R E N C E S}

Act, C.W., 1972. Clean Water Act of 1972. Public Law 92, 500 Andrews, E.D., Antweiler, R.C., 2012. Sediment fluxes from California coastal rivers: the influences of climate, geology, and topography. J. Geol. 120, 349-366.

Brewer, J.S., Menzel, T., 2009. A method for evaluating outcomes of restoration when no reference sites exist. Restor. Ecol. 17, 4-11.

Birk, S., Bonneb, W., Borjac, A., Brucetb, S., Courratd, A., Poikaneb, S., Soliminie, A., Van de Bundb, W., Zampoukasb, N., Heringa, D., 2012. Three hundred ways to assess Europe's surface waters: an almost complete overview of biological methods to implement the Water Framework Directive. Ecol. Indic. 18, 31-41.

Boulton, A.J., 1999. An overview of river health assessment: philosophies, practice, problems and prognosis. Freshw. Biol. 41, 469-479.

Breine, J., Simoens, I., Haidvogl, G., 2005. Manual for the application of the European Fish Index - EFI. A Fish-based Method to Assess the Ecological Status of European Rivers in Support of the Water Framework Directive. Version 1.1.

Cox, R., Wright, J.F., Furse, M.T., Moss, D., 1997. RIVPACSW (River Invertebrate Prediction and Classification System) User Manual.

Coysh, J., Nichols, S., Ransom, G., Simpson, J., Norris, R., Barmuta, L., Chessman, B., 2000. AUSRIVAS Macroinvertebrate Bioassessment Predictive Modelling Manual. Cooperative Research Centre for Freshwater Ecology, Canberra.

Davis, J.M., Baxter, C.V., Mineshall, G.W., Olson, N.F., Tang, C., Crosby, B.T., 2013. Climate-induced shift in hydrological regime alters basal resource dynamics in a wilderness river ecosystem. Freshw. Biol. 58, 306-319.

Dickens, C.W., Graham, P., 2002. The South African Scoring System (SASS) version 5 rapid bioassessment method for rivers. Afr. J. Aquat. Sci. 27, 1-10.

Dong, Z.R., 2005a. Overseas assessing technology for river health. Water Resour. Hydropower Eng. (in Chinese) 11, 15-19.

Dudgeon, D., 2012. Responses of benthic macroinvertebrate communities to altitude and geology in tributaries of the Sepik River (Papua New Guinea): the influence of taxonomic resolution on the detection of environmental gradients. Freshw. Biol. 57, 1794-1812.

Dong, Z.R., 2005b. The connotation of river health. China Water Resour. 04, 15-18.

Elliott, J.M., Drake, C.M., Tullet, P.A., 1980. The Choice of a Suitable Sampler for Benthic Macroinvertebrates in Deep Rivers. Freshwater Biological Association, Ambleside, UK (15 pp.).

Filser, J., Mebes, K.H., Winter, K., Lang, A., Kampichler, C., 2002. Long-term dynamics and interrelationships of soil Collembola and microorganisms in an arable landscape following land use change. Geoderma 105, 201-221.

Hellawell, J.M., 1986. Biological indicators of freshwater pollution and environmental management. In: Mellanby, K. (Ed.) Pollution Monitoring Series. Elsevier, Amsterdam. 
Hering, D., Moog, O., Sandin, L., Verdonschot, P.F.M., 2004. Overview and application of the AQEM assessment system. Hydrobiologia 516, 1-20.

Huang, K., Chen, Z.B., Chen, Z.Q., 2010. The spatial relationships of land use on different soil type within the watershed. Chin. Agric. Sci. Bull. 26, 329-334.

Jia, Y.W., Ding, X.Y., Wang, H., Zhou, Z.H., Qiu, Y.Q., Niu, C.W., 2012. Attribution of water resources evolution in the highly water-stressed Hai River Basin of China. Water Resour. Res. (in Chinese) 48, W02513.

Karr, J.R., 1981. Assessment of biotic integrity using fish communities. Fisheries 6, 21-27.

Karr, J.R., 1999. Biological integrity: a long-neglected aspect of water resource management. Ecol. Appl. 01, 66-84.

Lenat, D.R., Smock, L.A., Penrose, D.L., 1980. Use of benthic macroinvertebrates as indicators of environmental quality. In: Worf, D.L. (Ed.), Biological Monitoring for Environmental Effects. D.C. Heath, Lexington, MA, pp. 97-112.

Li, H.Y., 2013. Analysis on relations between urbanization and utilization of water resources in Hai River Basin. Yellow River (in Chinese) 02, 50-52.

Liu, X., Li, G.F., Liu, Z.G., Guo, W.H., Gao, N.Y., 2010. Water pollution characteristics and assessment of lower reaches in Hai River Basin. Procedia Environ. Sci. (in Chinese) 02, 199-206.

Marcarelli, A.M., Van Kirk, R.W., Baxter, C.V., 2010. Predicting effects of hydrologic alteration and climate change on ecosystem metabolism in a western U.S. river. Ecol. Appl. 20, 2081-2088.

Marsh, W.M., 1997. Landscape Planning: Environmental Applications. 3rd ed. John Wiley and Sons, Inc., New York, pp. 11-18.

Meng, W., Zhang, N., Zhang, Y., Zhang, B.H., 2009. Integrated assessment of river health based on water quality, aquatic life and physical habitat. J. Environ. Sci. (China) 21, 1017-1027.

Ni, J.R., Liu, Y.Y., 2006. River health diagnosis and ecological rehabilitation. China Water Resour. 13, 4-10.

Poquet, J.M., Alba-Tercedor, J., Puntı', T., Sa'nchez-Montoya, M.M., Robles, S., A'lvarez, M., Zamora-Muñoz, C., Sa'inz-Cantero, C.E., Vidal-Abarca, M.R., Sua'rez, M.L., Toro, M., Pujante, A.M., Rieradevall, M., Prat, N., 2009. The MEDiterranean Prediction And Classification System (MEDPACS): an implementation of the RIVPACS/AUSRIVAS predictive approach for assessing Mediterranean aquatic macroinvertebrate communities. Hydrobiologia 623, 153-171.

Ransom, G., Coysh, J., Nichols, S., 2005. Software V3.1 User Manual of AUSRIVAS (Australian River Assessment System).

Robert, C., Petersen, J.R., 1992. The RCE: a Riparian, Channel, and Environmental Inventory for small streams in the agricultural landscape. Freshw. Biol. 27, 295-306.
Sajedi, M., Shams-Kia, N., Haghiabi, A.H., 1997. The Effect of Soil Type, Shape and Slope of Rainwater Catchments on River Sediments. Soil Conservation \& Watershed Management Research Center, Tehran, pp. 863-867.

Schmidt-Kloiber, A., Nijboer, R.C., 2004. The effect of taxonomic resolution on the assessment of ecological water quality classes. Hydrobiologia 516, 269-283.

Shearer, K.A., Young, R.G., 2011. Influences of geology and land use on macroinvertebrate communities across the Motueka River catchment, New Zealand. N. Z. J. Mar. Freshw. 45, 437-454

Stoddard, J.L., Larsen, D.P., Hawkins, C.P., Johnson, R.K., Norris, R.H., 2006. Setting expectations for the ecological condition of streams: the concept of reference condition. Ecol. Appl. 16, 1267-1276.

Shen, X., Sun, T., 2012. Applications of Bayesian modeling to simulate ecosystem metabolism in response to hydrologic alteration and climate change in the Yellow River Estuary, China. 18th Biennial Isem Conference on Ecological Modelling for Global Change and Coupled Human and Natural System 13, pp. 790-796.

Slack, K.V., Averett, R.C., Greeson, P.E., Lipscomb, R.G., 1973. Methods for collection and analysis of aquatic biological and microbiological samples. Techniques of Water-resources Investigations of the United States Geological Survey. Book 5 US Department of the Interior, Geological Survey, Washington, DC, pp. 1-65 (chapter 4A).

Tang, T., Cai, Q.H., Liu, J.K., 2002. River ecosystem health and its assessment. Chin. J. Appl. Ecol. 13, 1191-1194.

The Editorial Board of Hai River, 1997. 1st ed. The Hai River Basin vol.1 (Beijing, China).

Wang, W.G., Shao, Q.X., Yang, T., Peng, S.Z., Xing, W.Q., Sun, F.C., 2013. Quantitative assessment of the impact of climate variability and human activities on runoff changes: a case study in four catchments of the Haihe River Basin, China. Hydrol. Process. 27, 1158-1174.

Wang, X., Li, J., Li, Y.X., Shen, Z.Y., Wang, X., Yang, Z.F., 2014. Is urban development an urban river killer? A case study of Yongding Diversion Channel in Beijing, China. J. Environ. Sci. (China) 26, 1232-1237.

Wei, X.H., Sun, G., 2009. Watershed Ecosystem Processes and Management1st ed. Higher Education Press, Beijing, China.

Wright, J.F., 1995. Development and use of a system for predicting macroinvertebrates in flowing waters. Aust. J. Ecol. 20, 181-197.

Yang, T., Liu, J.L., Chen, Q.Y., 2013. Assessment of plain river ecosystem function based on improved gray system model and analytic hierarchy process for the Fuyang River, Haihe River Basin, China. Ecol. Model. 268, 37-47. 